\title{
Adsorption of Quaternary Ammonium Compounds onto Activated Sludge
}

\author{
Rong Ren, Dongfang Liu, Kexun Li, Jie Sun, Chong Zhang \\ College of Environmental Science and Engineering/Tianjin Key Laboratory of Environmental \\ Remediation and Pollution Control/Ministry of Education Key Laboratory of Pollution Processes \\ and Environmental Criteria, Nankai University, Tianjin, China \\ E-mail:Likx@nankai.edu.cn \\ Received November 28, 2010; revised January 3, 2011; accepted February 8, 2011
}

\begin{abstract}
The performance of activated sludge in the removal of tetradecyl benzyl dimethyl ammonium chloride $\left(\mathrm{C}_{14} \mathrm{BDMA}\right)$ by adsorption from aqueous solution was investigated with different $\mathrm{PH}$, contact time, ionic strength and temperature. Equilibrium was achieved within $2 \mathrm{~h}$ of contact time. The adsorption capacity increased largely with increasing solution $\mathrm{pH}$ and remained constant above $\mathrm{pH}$ 9. The ionic strength had a negative effect on $\mathrm{C}_{14} \mathrm{BDMA}$ removal. The adsorption isotherms were analyzed by Langmuir and Freundlich isotherm models, and equilibrium partitioning data was described well by both models. Kinetics data was best described by the pseudo second-order model. Experimental results indicated that the adsorption was favorable at lower temperatures. Thermodynamic parameters, including the Gibbs free energy $\left(\Delta G^{0}\right)$, enthalpy $\left(\Delta H^{0}\right)$, and entropy $\left(\Delta S^{0}\right)$, were also calculated. These parameters indicated that adsorption of $\mathrm{C}_{14} \mathrm{BDMA}$ onto activated sludge was feasible, spontaneous and exothermic in the temperature range of $15-35^{\circ} \mathrm{C}$. The activated sludge was shown to be an effective adsorbent for $\mathrm{C}_{14} \mathrm{BDMA}$.
\end{abstract}

Keywords: Activated Sludge, Adsorption, Kinetics, Quaternary Ammonium Compounds, Thermodynamics Analysis

\section{Introduction}

Quaternary ammonium compounds (QACs) are molecules with at least one hydrophobic hydrocarbon chain linked to a positively charged nitrogen atom with other alkyl or aryl groups being mostly short-chain substituent [1]. QACs belong to the group of cationic surfactants. Because of their unique physical/chemical properties, QACs are primarily used as disinfectants, biocides or detergents, but QACs are also used as anti-electrostatics and phase transfer catalysts in a wide range of applications [2].

The widespread use of QACs causes them to be released and to accumulate in aquatic environments and wastewater treatment plants (WWTPs) [3-4]. Due to their biocidal properties they may have potential impacts on organisms in activated sludge. It was revealed in literature that QACs had an adverse effect on nitrification [5] and denitrification [6]. Moreover, it was reported that QACs, at a concentration of $50 \mathrm{mg} \mathrm{L}{ }^{-1}$, adversely affected the anaerobic degradation, which resulted in significantly reduced methane production and accumulation of volatile fatty acids [7]. Due to the hydrophobic and electrostatic interactions, QACs can rapidly adsorb onto solids and extensively accumulate in aquatic sediments [4, 8-10]. The adsorption of QACs has been studied previously using various adsorbents, such as coal [11], clinoptilolite [12], and activated carbon [13-15].

Activated sludge is a well-known biomass used for the purification of both industrial effluent and domestic wastes. Although a large number of studies have reported on biosorption of heavy metals as well as organic pollutants onto activated sludge [16-18], there have been few studies on the use of sludge to remove QACs [19-22]. Garcia et al. [20] investigated the adsorption isotherms on activated sludge from wastewater treatment plants and surface properties in aqueous solutions of alkyl benzyl dimethyl ammonium compounds (BAC). They reported that the Langmuir and Freundlich isotherms agreed very well with experimental data, and adsorption capacity increased with increasing the alkyl chain length. 
The objective of this study was to investigate the adsorption potential of activated sludge for removal of Tetradecyl benzyl dimethyl ammonium chloride $\left(\mathrm{C}_{14} \mathrm{BDMA}\right)$, which is one of the most commonly used QACs. Effects of different parameters, such as $\mathrm{pH}$, contact time, temperature and ionic strength on the adsorption were investigated. The adsorption thermodynamics and kinetics of $\mathrm{C}_{14} \mathrm{BDMA}$ onto activated sludge were evaluated.

\section{Materials and Methods}

\subsection{Preparation of the Adsorbent}

The activated sludge used in this study was obtained from the wastewater treatment plant of the Technical and Economic Development Area (TEDA) in Tianjin, China. The activated sludge was centrifuged at $1750 \mathrm{~g}$ for $5 \mathrm{~min}$ and washed twice with DI water to remove easily suspended materials. The remaining solids were placed into flasks, immediately inactivated by autoclaving $\left(120^{\circ} \mathrm{C}\right.$, $30 \mathrm{~min}$ ), and then stored at $4{ }^{\circ} \mathrm{C}$ to ensure that only the adsorption effect, rather than a combined adsorption and degradation effect, was assessed.

\subsection{Chemicals}

Tetradecyl benzyl dimethyl ammonium chloride $\left(\mathrm{C}_{14} \mathrm{BD}-\right.$ $\mathrm{MA}, \mathrm{C}_{23} \mathrm{H}_{42} \mathrm{NCl}, 368.0 \mathrm{~g} \mathrm{~mol}^{-1}$ ) used in this study was purchased from Shanghai Jinchun company in China and was used without further purification. Stock solution (10 $\mathrm{g} \mathrm{L}^{-1}$ ) of $\mathrm{C}_{14} \mathrm{BDMA}$ was prepared based on the active ingredient purity and concentration and was used in all experiments after dilution with DI water.

\subsection{Adsorption Experiments}

Kinetic removal of $\mathrm{C}_{14} \mathrm{BDMA}$ was performed as follows: batch experiments were conducted using $250 \mathrm{~mL}$ screw-topped flasks, and the mixed liquor suspended solids (MLSS) was $250 \mathrm{mg} \mathrm{L}^{-1}$. A sample of $\mathrm{C}_{14}$ BDMA solution was then added to attain the desired initial $\mathrm{C}_{14}$ BDMA concentrations $\left(5,20,50 \mathrm{mg} \mathrm{L}^{-1}\right)$. The flasks were sealed with stoppers and shaken at a rate of 150 rpm with a shaker at room temperature, and samples were obtained at given time intervals $(0,0.25,0.5,1,2,4$ and $8 \mathrm{~h}$ ). After centrifugation (11,410 $\mathrm{g}$ for $15 \mathrm{~min})$, the liquid phase concentration was measured, and the mass of $\mathrm{C}_{14} \mathrm{BDMA}$ adsorbed to the sludge was calculated based on the difference between the total and aqueous $\mathrm{C}_{14} \mathrm{BDMA}$ mass. Blank experiments were carried out with $\mathrm{C}_{14} \mathrm{BDMA}$ solution and without adsorbent to ensure that no $\mathrm{C}_{14} \mathrm{BDMA}$ was adsorbed onto the walls of the flasks.
Adsorption isotherm assays were determined at initial $\mathrm{C}_{14}$ BDMA concentrations of $10,20,40,60,80,100,120$, $140 \mathrm{mg} \mathrm{L}^{-1}$ and $250 \mathrm{mg} \mathrm{L}^{-1}$ sludge concentration (MLSS). The flasks were shaken at a rate of $150 \mathrm{rpm}$ with a shaker for $4 \mathrm{~h}$. The experiments were repeated at 15, 25, and $35^{\circ} \mathrm{C}$. When the sorption procedure was completed, the samples and data were treated in the same way as in the kinetic experiments.

In order to evaluate the effect of $\mathrm{pH}$ and ionic strength on the adsorption of $\mathrm{C}_{14} \mathrm{BDMA}$ onto activated sludge, the adsorption experiments were carried out over a $\mathrm{pH}$ range of $1-13$ and the concentrations of $\mathrm{NaCl}$ ranging from 0 to $0.40 \mathrm{~mol} \mathrm{~L}^{-1}$, respectively.

\subsection{Analytical Methods}

The concentrations of QACs in whole and centrifuged sludge samples were determined by using the previously reported modified disulfine blue (DSB) method [23]. The Mixed liquor suspended solids (MLSS), mixed liquor volatile suspended solids (MLVSS) and $\mathrm{pH}$ were measured according to the Standard [24].

\section{Results and Discussion}

\subsection{Effect of Contact Time}

In order to establish the equilibration time for maximum uptake, the adsorption of $\mathrm{C}_{14} \mathrm{BDMA}$ onto activated sludge was studied as a function of contact time.

The adsorption rate was high at the beginning, and equilibrium adsorption of $\mathrm{C}_{14} \mathrm{BDMA}$ onto activated sludge was achieved within $2 \mathrm{~h}$ (Figure 1). Therefore the equilibration period of $4 \mathrm{~h}$ was selected for all further experiments. The rapid attainment of equilibrium was consistent with previously published reports on the adsorption of cationic surfactants onto sludge. Ismail et al. [21] investigated the batch adsorption of four tested QACs to sludge and reported the optimum equilibrium time as $4 \mathrm{~h}$. All the systems studied by Garcia et al. [25] to determine the rate of BAC adsorption onto activated sludge achieved equilibrium within three hours.

Figure 1 also shows that the uptake of the $\mathrm{C}_{14} \mathrm{BDMA}$ increased with increasing initial $\mathrm{C}_{14} \mathrm{BDMA}$ concentration. Raising the initial $\mathrm{C}_{14} \mathrm{BDMA}$ concentration from 5 to 50 $\mathrm{mg} \mathrm{L}^{-1}$ allows the sludge to increase the adsorption capacity from 17.61 to $148.5 \mathrm{mg} \mathrm{g}^{-1}$. The results are in agreement with literature on the adsorption of organic substances onto activated sludge [26,27]. This is due to an increase in the driving force of the concentration gradient as an increase in the initial adsorbate concentration. The initial concentration is an important driving force to overcome all mass transfer resistances of the $\mathrm{C}_{14} \mathrm{BDMA}$ 


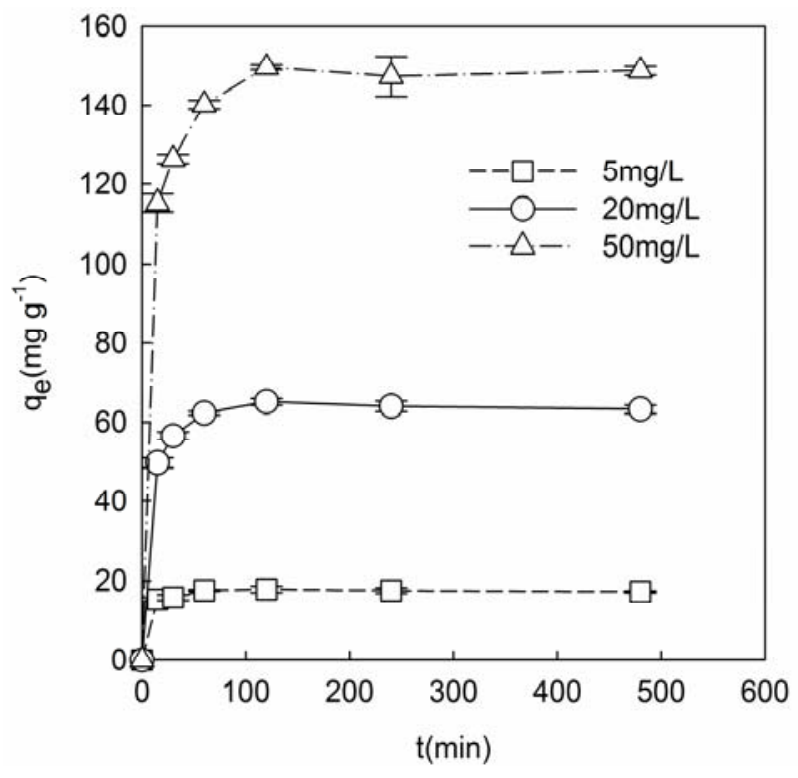

Figure 1. Kinetic study for $\mathrm{C}_{14} \mathrm{BDMA}$ adsorption onto activated sludge. (MLSS: $0.25 \mathrm{~g} \mathrm{~L}^{-1}$; temperature: $25^{\circ} \mathrm{C}$ ). (Error bars represent one standard deviation of the means).

between the aqueous and solid phases. Thus, a higher initial concentration would enhance the adsorption process.

\subsection{Adsorption Kinetics}

The adsorption kinetics data is extremely important to understand the mechanism of the adsorption and to assess the performance of the adsorbents. The pseudo firstorder adsorption [28], the pseudo second-order adsorption [29] and the intra-particle diffusion models [30] were used to fit the experimental data.

The parameters in the psuedo first and second-order models determined from the linear plots of $\ln \left(q_{e}-q_{t}\right)$ versus $t$ (Figure 2) and $t / q_{t}$ versus $t$ (Figure 3 ) are given in Table 1. The correlation coefficients $\left(R^{2}\right)$ for the pseudo first-order model, were relatively too low, which may be indicative of a bad correlation. The $q_{\text {ecal }}$ values determined from the model were not consistent with the experimental values of $q_{e}$ (not shown in the table). Therefore, the pseudo first-order reaction is not suitable for adsorption of $\mathrm{C}_{14} \mathrm{BDMA}$ onto sludge. However, the correlation coefficients for the pseudo second-order kinetic model are close to 1.0 for all cases $\left(R^{2}=0.999\right)$, and the theoretical values of $q_{e c}$ were in agreement with the experimental data $q_{e}$. Based on these results, the adsorption of $\mathrm{C}_{14} \mathrm{BDMA}$ onto activated sludge followed the pseudo second-order process rather than pseudo firstorder. The results presented in this study are comparable to a study which investigated the biosorption of cationic surfactants by using activated carbon cloth [14].

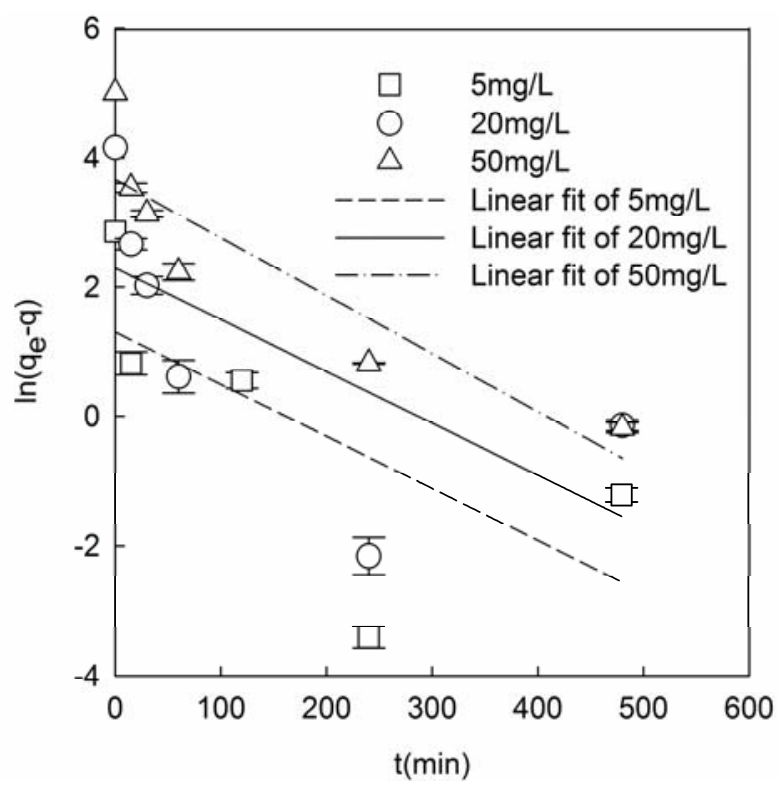

Figure 2. Linearized pseudo first-order kinetic model for adsorption of $\mathrm{C}_{14} \mathrm{BDMA}$ onto activated sludge at various initial concentration. (MLSS: $0.25 \mathrm{~g} \mathrm{~L}^{-1}$; temperature: $25^{\circ} \mathrm{C}$ ). (Error bars represent one standard deviation of the means).

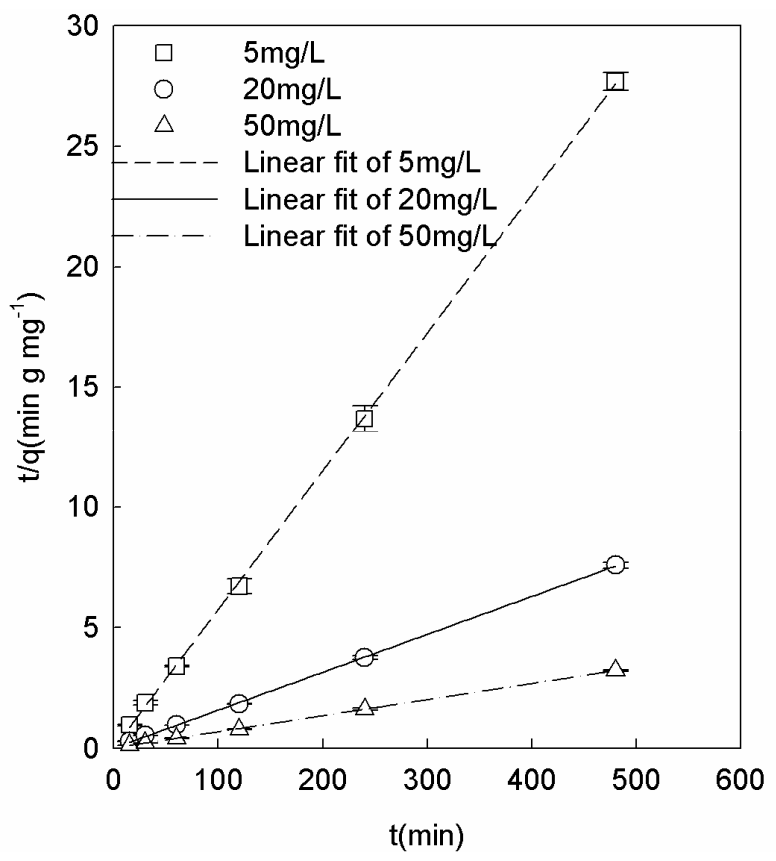

Figure 3. Linearized pseudo second-order kinetic model for adsorption of $\mathrm{C}_{14} \mathrm{BDMA}$ onto activated sludge at various initial concentration. (MLSS: $0.25 \mathrm{~g} \mathrm{~L}^{-1}$; temperature: 25 ${ }^{\circ} \mathrm{C}$ ). (Error bars represent one standard deviation of the means).

The psuedo first and second-order models basically include all steps of sorption, such as external film diffusion, sorption, and internal particle diffusion, so they are 
Table 1. Pseudo first-order and pseudo second-order adsorption rate constants of $\mathrm{C}_{14}$ BDMA onto activated sludge at different initial concentration.

\begin{tabular}{|c|c|c|c|c|c|c|}
\hline \multirow{2}{*}{$\begin{array}{c}C_{0} \\
\left(\mathrm{mg} \mathrm{L}^{-1}\right)\end{array}$} & \multirow{2}{*}{$\begin{array}{l}\text { Meas- } \\
\text { ured } q_{e} \\
\left(\mathrm{mg} \mathrm{g}^{-1}\right)\end{array}$} & \multicolumn{2}{|c|}{$\begin{array}{l}\text { Pseudo } \\
\text { first-order } \\
\text { constants }\end{array}$} & \multicolumn{3}{|c|}{ Pseudo second-order constants } \\
\hline & & $\begin{array}{c}k_{1} \\
\left(\min ^{-1}\right)\end{array}$ & $R^{2}$ & $\begin{array}{c}k_{2} \\
\left(\mathrm{~g} \mathrm{mg}^{-1} \min ^{-1}\right)\end{array}$ & $\begin{array}{c}q_{e c} \\
\left(\mathrm{mg} \mathrm{g}^{-1}\right)\end{array}$ & $R^{2}$ \\
\hline 5 & 17.61 & 0.008 & 0.454 & 0.221 & 17.42 & 0.999 \\
\hline 20 & 64.09 & 0.008 & 0.458 & 0.010 & 63.69 & 0.999 \\
\hline 50 & 148.5 & 0.167 & 0.838 & 0.002 & 149.3 & 0.999 \\
\hline
\end{tabular}

considered pseudo-models. Neither model identifies the sorption mechanism, so the intra-particle diffusion model was tested in this work. According to previous studies, the intra-particle diffusion plot may represent multilinearity, indicating that two or more steps occur [31-33]. The first portion (sharper) is the external surfaces sorption or instantaneous sorption stage. The second portion is the gradual sorption stage, where intra-particle diffusion is rate-controlled. The third portion is the final equilibrium stage, where intra-particle diffusion starts to slow down due to extremely low solute concentrations in the solution.

The intra-particle diffusion plot for the sorption of $\mathrm{C}_{14} \mathrm{BDMA}$ is shown in Figure 4. It was observed that the data points were related by two straight lines and the plots did not pass through the origin. The deviation of the straight lines from the origin may be due to the difference in the rate of mass transfer during the initial and

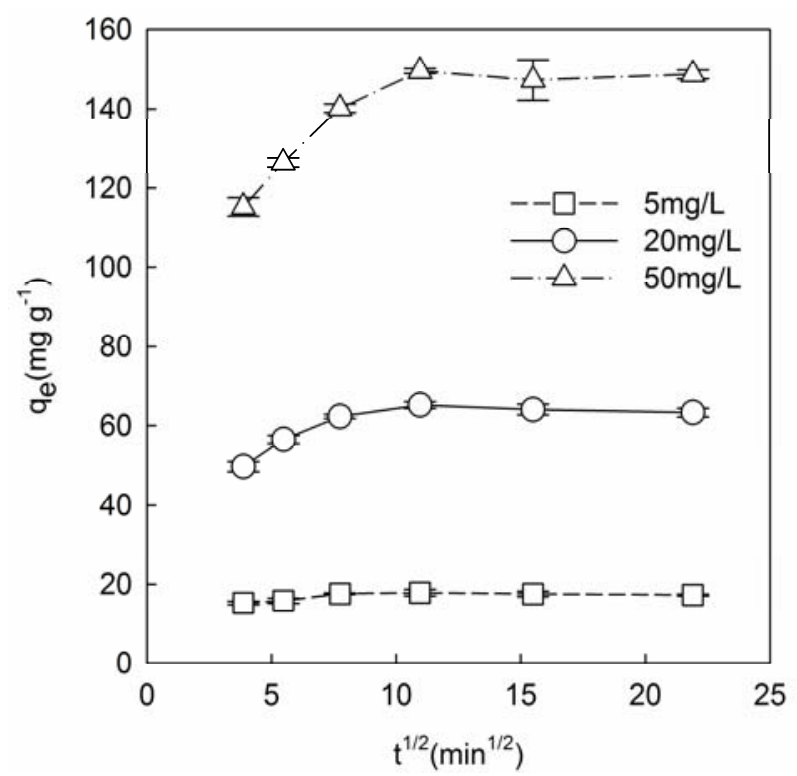

Figure 4. Intra-particle diffusion model for adsorption of $\mathrm{C}_{14}$ BDMA onto activated sludge at various initial concentrations. (MLSS: $0.25 \mathrm{~g} \mathrm{~L}^{-1}$; temperature: $25^{\circ} \mathrm{C}$ ). (Error bars represent one standard deviation of the means). final stages of adsorption. The intercepts, obtained by extrapolation of the linear portion of the plots, provide the boundary layer thickness. The initial curved portion is attributed to boundary layer diffusion effects or external mass transfer effects $[34,35]$. These effects indicated that intra-particle diffusion was not the only rate-limiting step; also, other kinetic models, such as surface adsorption, may control the rate of adsorption.

\subsection{Adsorption Isotherms}

The experiments were carried out with initial $\mathrm{C}_{14} \mathrm{BDMA}$ concentrations in the range of $10-140 \mathrm{mg} \mathrm{L}^{-1}$ at $25^{\circ} \mathrm{C}$. The sludge concentration (MLSS) was $250 \mathrm{mg} \mathrm{L}^{-1}$ and contact time was $4 \mathrm{~h}$.

The equilibrium data was fitted with the Langmuir [36] and Freundlich [37] isotherm models. The Langmuir parameters, $q_{m}$, which is the maximum amount of adsorption and $K_{L}$, which is the Langmuir adsorption constant, obtained from the equation of plot of $q_{e}$ versus $C_{e}$ (Figure 5), were found to be $368.3 \mathrm{mg} \mathrm{g}^{-1}$ and $0.047 \mathrm{~L}$ $\mathrm{mg}^{-1}$, with a correlation coefficient $\left(R^{2}\right)$ of 0.984 ; results are listed in Table 2. The fitted results indicate that the Langmuir isotherm model was applicable to describing the $\mathrm{C}_{14} \mathrm{BDMA}$ adsorption equilibrium by inactivated sludge.

The Freundlich adsorption isotherms are also shown in Figure 5. The values of $K_{F}$ which is the constant related to the adsorption capacity obtained in this study are higher than previously reported values $[21,38]$. The $K_{F}$ and $n$

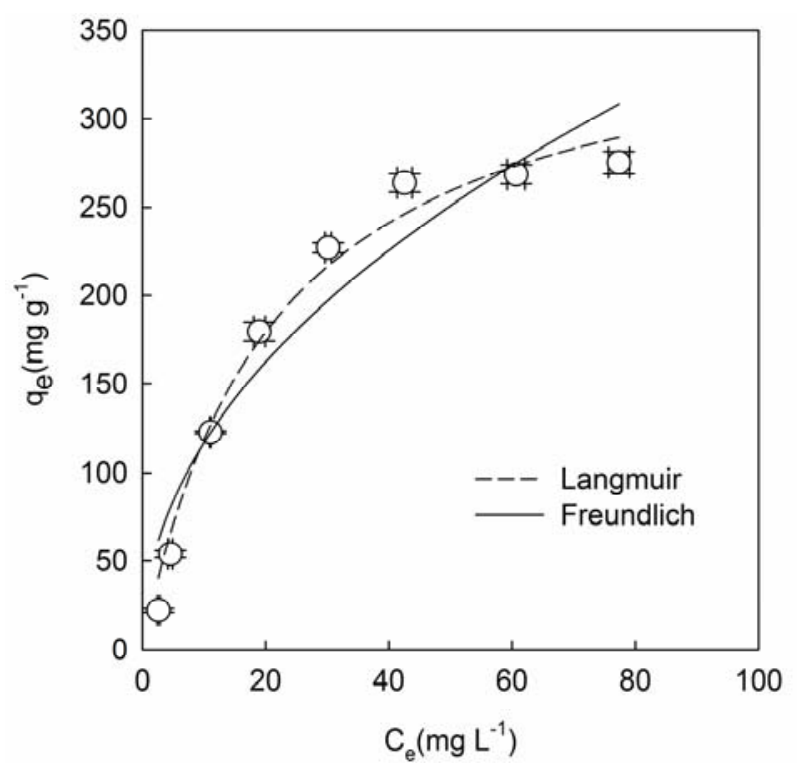

Figure 5. Equilibrium adsorption isotherms for adsorption of $\mathrm{C}_{14} \mathrm{BDMA}$ onto activated sludge at $25{ }^{\circ} \mathrm{C}$. (MLSS: $0.25 \mathrm{~g}$ $L^{-1}$; contact time: $4 \mathrm{~h}$ ). (Error bars represent one standard deviation of the means). 
Table 2. Isotherm constants for the adsorption of $\mathrm{C}_{14} \mathrm{BDMA}$ onto activated sludge at $25^{\circ} \mathrm{C}$.

\begin{tabular}{ccccccc}
\hline & \multicolumn{3}{c}{ Freundlich model } & \multicolumn{3}{c}{ Langmuir model } \\
\cline { 2 - 7 }$\left({ }^{\circ} \mathrm{C}\right)$ & $K_{F}$ & $n$ & $R^{2}$ & $\begin{array}{c}K_{L} \\
\left(\mathrm{~L} \mathrm{mg}^{-1}\right)\end{array}$ & $\begin{array}{c}q_{m} \\
\left(\mathrm{mg} \mathrm{g}^{-1}\right)\end{array}$ & $R^{2}$ \\
\hline 25 & 39.17 & 2.112 & 0.918 & 0.047 & 368.3 & 0.984 \\
\hline
\end{tabular}

calculated from the plots, along with the regression correlation coefficients, are given in Table 2. The value of $n$ varies with the heterogeneity of the adsorbent and should be less than 10 and higher than 1 for a favorable adsorption process. The Freundlich constant $1 / n$ obtained in this study was smaller than 1 , which indicated that the adsorption process was favorable under studied conditions. According to the correlation coefficient (0.918), the adsorption pattern of $\mathrm{C}_{14} \mathrm{BDMA}$ onto sludge was also well fitted with the Freundlich isotherm models. This may be due to both homogeneous and heterogeneous distribution of active sites on the surface of the sludge. This observation was in agreement with that of Garcia et al. [20] mentioned above. However, equilibrium partitioning data obtained from the adsorption of cationic surfactants onto municipal sludge [21] and activated carbon cloth [14] were described by the Freundlich isotherm model; these results may be caused by differences in the absorbents rather than the adsorbates.

\subsection{Effect of Adsorption Temperature}

The effect of temperature on the adsorption isotherm was investigated under isothermal conditions in the temperature range of $15-35^{\circ} \mathrm{C}$. Figure 6 shows the temperature dependence of $\mathrm{C}_{14} \mathrm{BDMA}$ adsorption onto activated sludge. The experimental results indicate that the magnitude of $\mathrm{C}_{14} \mathrm{BDMA}$ adsorption is closely related to the solution temperature. The adsorption capacity decreased when temperature rose from $15-35^{\circ} \mathrm{C}$, indicating that $\mathrm{C}_{14} \mathrm{BDMA}$ uptake was favored at lower temperatures. Literature has shown many cases in which the increase in temperature caused a decrease in the adsorption capacity of different adsorbates $[39,40]$. This might be due to the weakening of adsorptive forces between the active sites of the adsorbent and adsorbate species and between the vicinal molecules of the adsorbed phase.

In order to gain insight into the mechanisms involved in the adsorption process, thermodynamic parameters for the present system were calculated at different temperatures. The variations in the enthalpy $\left(\Delta H^{0}\right)$, and entropy $\left(\Delta S^{0}\right)$ were calculated were calculated from the slope and intercept of the plot between $\ln K_{d}$ versus 1/T (Figure 7). $K_{d}$ is the distribution coefficient and $T$ is the absolute temperature (K). $\Delta G^{0}$ can be calculated using the Gibbs Free Energy Equation [41]. According to Table 3, the

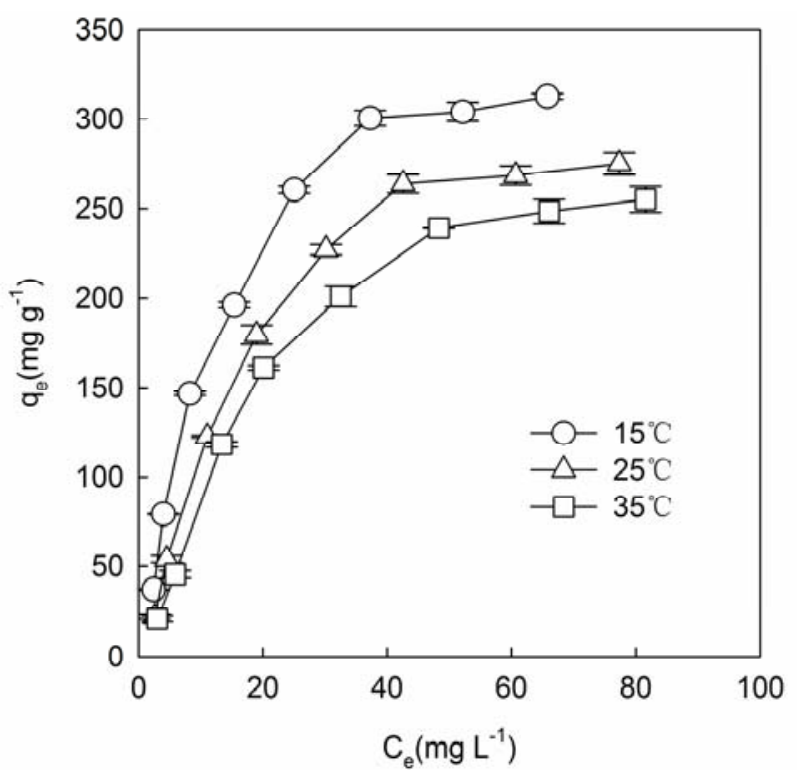

Figure 6. $\mathrm{C}_{14} \mathrm{BDMA}$ adsorption isotherm onto activated sludge at different temperatures. (Error bars represent one standard deviation of the means).

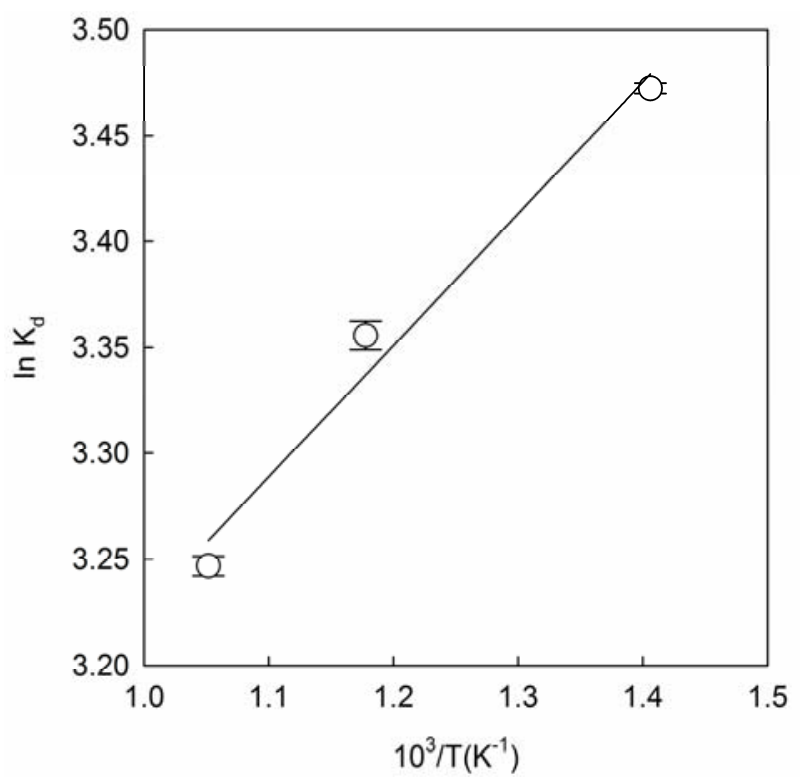

Figure 7. Van't Hoff plot for the adsorption of $\mathrm{C}_{14}$ BDMA onto activated sludge. (Error bars represent one standard deviation of the means).

negative values of $\Delta G^{0}$ indicated that the adsorption process was feasible and spontaneous. In addition, the free energy increased from -3.336 to $-2.648 \mathrm{~kJ} \mathrm{~mol}^{-1}$ with an increase of temperature from $15-35^{\circ} \mathrm{C}$, showing a decrease in spontaneity.

The negative value of $\Delta H^{0}$ confirmed the exothermic nature of adsorption, also supported by the decrease in value of $\mathrm{C}_{14} \mathrm{BDMA}$ uptake with the rise in temperature. 
Table 3. Thermodynamic parameters of the $\mathrm{C}_{14} \mathrm{BDMA}$ adsorption onto activated sludge at different temperatures.

\begin{tabular}{cccc}
\hline$T\left({ }^{\circ} \mathrm{C}\right)$ & $\Delta G^{0}\left(\mathrm{~kJ} \mathrm{~mol}^{-1}\right)$ & $\Delta H^{0}\left(\mathrm{~kJ} \mathrm{~mol}^{-1}\right)$ & $\Delta S^{0}\left(\mathrm{~J} \mathrm{~mol}^{-1} \mathrm{~K}^{-1}\right)$ \\
\hline 15 & -3.336 & & \\
25 & -2.992 & -13.11 & -33.94 \\
35 & -2.648 & & \\
\hline
\end{tabular}

Enthalpy change data is useful for distinguishing physisorption and chemisorption. Physisorption is typically associated with heats of adsorption in the $5-20 \mathrm{~kJ} \mathrm{~mol}^{-1}$ range, while chemisorption is typically associated with much larger $\Delta H^{0}$ values $\left(100-400 \mathrm{~kJ} \mathrm{~mol}^{-1}\right)$ [42]. The current results suggest that adsorption processes were primarily physisorption.

The entropy change $\left(\Delta S^{0}\right)$ was $-33.94 \mathrm{~J} \mathrm{~mol}^{-1} \mathrm{~K}^{-1}$, which means that $\mathrm{C}_{14} \mathrm{BDMA}$ sorption to activated sludge corresponds to a decrease in entropy. The negative value of $\Delta S^{0}$ suggests the decreased randomness at the solid/ liquid interface during adsorption. This finding indicates that the changes associated with molecular ordering actually impede the sorption process. $\mathrm{C}_{14} \mathrm{BDMA}$ is relatively hydrophobic $(\log \mathrm{Kow}=3.91)$ [43], which suggests that hydrophobic interactions may cause sorption to be entropically driven; the current results are in conflict with this notion. Similar results were observed in $17 \alpha$-Ethinylestradiol $\left(\mathrm{EE}_{2}\right)$ adsorption onto activated sludge [44]. Hydrophobic interactions are hypothesized to result in greater overall system entropy because of the decrease in the ordering of water molecules surrounding the hydrophobic compounds of interest.

\subsection{Effect of pH}

Figure 8 shows the $\mathrm{pH}$ dependence of $\mathrm{C}_{14} \mathrm{BDMA}$ adsorption onto activated sludge. As shown, the removal of $\mathrm{C}_{14} \mathrm{BDMA}$ from aqueous solution was strongly affected by solution $\mathrm{pH}$. The amount of $\mathrm{C}_{14} \mathrm{BDMA}$ adsorbed onto activated sludge was found to increase from 78.66 to $199.7 \mathrm{mg} \mathrm{g}^{-1}$ in the $\mathrm{pH}$ range of $1-9$ and attained a constant value above $\mathrm{pH} 9$.

The lower adsorption at lower $\mathrm{pH}$ may be attributed to the presence of excess protons in solution competing with cations for the adsorption, and electrostatic repulsion exists between the positively charged surface and the positively charged $\mathrm{C}_{14} \mathrm{BDMA}$ molecule. $\mathrm{pH}_{\mathrm{ZPC}}$ is the required $\mathrm{pH}$ value to give a zero net surface charge on the adsorbent. When $\mathrm{pH}$ is lower than $\mathrm{pH}_{\mathrm{ZPC}}$, the number of negatively charged adsorbent sites decreases, and the number of positively charged surface sites increases, which favors the adsorption of anions [45]. Moreover, the cations in solution may compete with $\mathrm{C}_{14}$ BDMA for sorption sites, resulting in the reduction or inhibition of the binding of $\mathrm{C}_{14} \mathrm{BDMA}$. Therefore, the sorption of

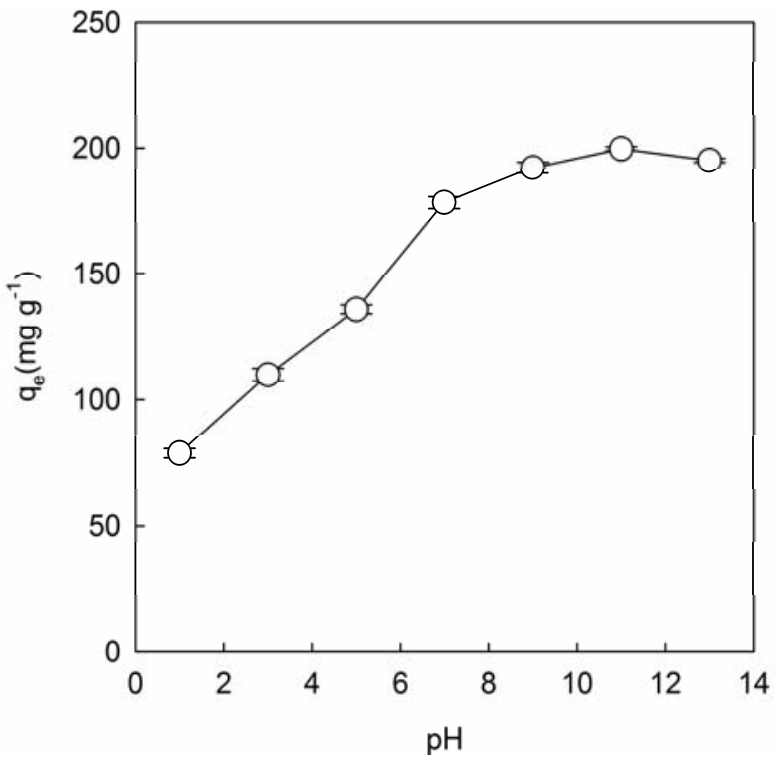

Figure 8. Effect of $\mathrm{pH}$ for the adsorption of $\mathrm{C}_{14} \mathrm{BDMA}$ onto activated sludge. $\left(C_{14} B D M A\right.$ concentration: $50 \mathrm{mg} \mathrm{L}^{-1}$; MLSS: $0.25 \mathrm{~g} \mathrm{~L}^{-1}$; contact time: $4 \mathrm{~h}$; temperature: $25^{\circ} \mathrm{C}$ ). (Error bars represent one standard deviation of the means).

$\mathrm{C}_{14} \mathrm{BDMA}$ at the low $\mathrm{pH}$ range takes place with low removal efficiency.

In general, adsorption of cations is favored at $\mathrm{pH}>$ pHpzc. For $\mathrm{pH}$ values above the $\mathrm{pH}_{\mathrm{ZPC}}$, the cell walls will have a negative net charge, which promotes electrostatic attractions between positively charged cations and negatively charged binding sites. Similar observations are shown in literature for cetyl trimethyl ammonium bromide (CTAB) in a $\mathrm{pH}$ range of 2-10 using coal samples, as reported by Mishra and Panda [11].

\subsection{Effect of Ionic Strength}

Industrial wastewaters and natural waters contain many types of electrolytes that have significant effects on the adsorption process, so it is important to evaluate the effects of ionic strength on the removal of $\mathrm{C}_{14}$ BDMA from aqueous solutions.

Figure 9 shows the influence of ionic strength on the $\mathrm{C}_{14}$ BDMA adsorption. Results showed that an increase in ionic strength led to a decrease of $\mathrm{C}_{14}$ BDMA adsorption onto activated sludge. As the concentration of $\mathrm{NaCl}$ increased from 0 to $0.40 \mathrm{~mol} \mathrm{~L}^{-1}$, the amount of $\mathrm{C}_{14} \mathrm{~B}$ DMA uptake decreased from 158.1 to $102.3 \mathrm{mg} \mathrm{g}^{-1}$. Similar trends were also reported in studies on the sorption of $17 \alpha$-ethinylestradiol onto activated sewage sludge [46] and the sorption of dyes onto metal hydroxide sludge [47].

The aqueous solubilities of different kinds of compounds decrease in the presence of inorganic salts; this is 


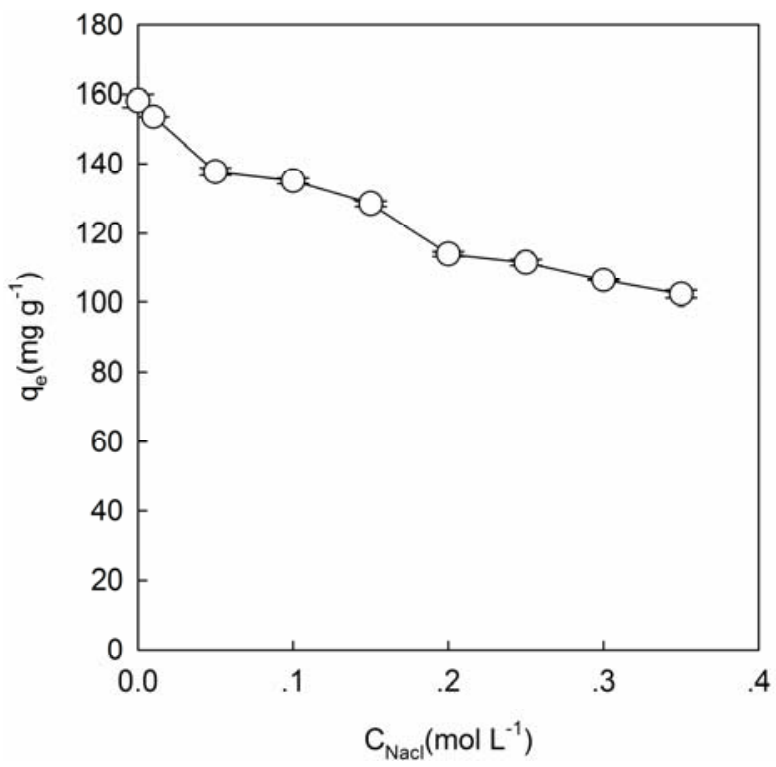

Figure 9. Effect of ionic strength on the adsorption of $\mathrm{C}_{14}$ BDMA onto activated sludge $\left(\mathrm{C}_{14} \mathrm{BDMA}\right.$ concentration: $50 \mathrm{mg} \mathrm{L}^{-1}$; MLSS: $0.25 \mathrm{~g} \mathrm{~L}^{-1}$; contact time: $4 \mathrm{~h}$; temperature: $25^{\circ} \mathrm{C}$ ). (Error bars represent one standard deviation of the means).

called the salting-out effect. Therefore, the salting-out effect of $\mathrm{NaCl}$ on $\mathrm{C}_{14} \mathrm{BDMA}$ would be evident with the increase of ion strength, resulting in the reduction of $\mathrm{C}_{14} \mathrm{BDMA}$ concentration in aqueous solution. This led to a new distribution equilibrium between water and sludge phases and decreased the adsorption of $\mathrm{C}_{14} \mathrm{BDMA}$ onto the activated sludge $[46,48]$. Moreover, $\mathrm{Na}^{+}$and positively charged $\mathrm{C}_{14} \mathrm{BDMA}$ molecules competed for the same binding sites on the biosorbent surface. With the increase of ionic strength, the number of active sites available for $\mathrm{C}_{14} \mathrm{BDMA}$ adsorption decreases.

\section{Conclusions}

In this study, the kinetic studies indicated that the adsorption rate was high at the beginning and the equilibrium time was $2 \mathrm{~h}$. The kinetics of $\mathrm{C}_{14} \mathrm{BDMA}$ adsorption onto activated sludge followed the pseudo second-order model. The curves obtained for the Langmuir and Freundlich isotherm models described the experimental equilibrium data well, indicating both heterogeneous and homogeneous distributions in the active site on the surface. The adsorption of $\mathrm{C}_{14} \mathrm{BDMA}$ onto activated sludge decreased with increasing temperature. Thermodynamic parameters, including the Gibbs free energy $\left(\Delta G^{0}\right)$, enthalpy $\left(\Delta H^{0}\right)$, and entropy $\left(\Delta S^{0}\right)$, indicated that adsorption of $\mathrm{C}_{14} \mathrm{BDMA}$ onto activated sludge was feasible, spontaneous and exothermic in the temperature range of $15-35^{\circ} \mathrm{C}$. The adsorption of $\mathrm{C}_{14} \mathrm{BDMA}$ on activated sludge was found to be low in acidic solution but increases with an increase in $\mathrm{pH}$ and remains constant in the neutral and alkaline $\mathrm{pH}$ regions. As the concentration of $\mathrm{NaCl}$ increased, the amount of $\mathrm{C}_{14} \mathrm{BDMA}$ uptake decreased. The experimental results indicated that the activated sludge could be used as an alternative, inexpensive and effective material to remove high amounts of $\mathrm{C}_{14} \mathrm{BDMA}$ from wastewater.

\section{Acknowledgements}

This work was financially supported by the National water pollution control and treatment technological project (No. 2008ZX07314-002) and the National Natural Science Foundation of China (No. 50908117).

\section{References}

[1] E. Martinez-Carballo, A. Sitka, C. Gonzalez-Barreiro, N. Kreuzinger, M. Furhacker, S. Scharf and O. Gans, "Determination of Selected Quaternary Ammonium Compounds by Liquid Chromatography with Mass Spectrometry. Part I. Application to Surface, Waste and Indirect Discharge Water Samples in Austria," Environmental Pollution, Vol. 145, No. 2, 2007, pp. 489-496. doi:10.1016/j.envpol.2006.04.033

[2] N. Kreuzinger, M. Fuerhacker, S. Scharf, M. Uhl, O. Gans and B. Grillitsch, "Methodological Approach towards the Environmental Significance of Uncharacterized Substances-Quaternary Ammonium Compounds as an Example," Desalination, Vol. 215, No. 1-3, 2007, pp. 209-222. doi:10.1016/j.desal.2006.10.036

[3] L. Games, J. King and R. Larson, "Fate and Distribution of a Quaternary Ammonium Surfactant, Octadecyl Trimethyl Ammonium Chloride (OTAC), in Wastewater Treatment," Environmental Science \& Technology, Vol. 16, No. 8, 1982, pp. 483-488. doi:10.1021/es00102a011

[4] H. Sun, A. Takata, N. Hata, I. Kasahara and S. Taguchi, "Transportation and Fate of Cationic Surfactant in River Water," Journal of Environmental Monitoring, Vol. 5, No. 6, 2003, pp. 891-895. doi:10.1039/b308988f

[5] R. Boethling, "Environmental Fate and Toxicity in Wastewater Treatment of Quaternary Ammonium Surfactants," Water Research, Vol. 18, No. 9, 1984, pp. 10611076. doi:10.1016/0043-1354(84)90220-3

[6] U. Tezel, J. Pierson and S. Pavlostathis, "Effect of Didecyl Dimethyl Ammonium Chloride on Nitrate Reduction in a Mixed Methanogenic Culture," Water Science and Technology: A Journal of the International Association on Water Pollution Research, Vol. 57, No. 4, 2008, pp. 541-546.

[7] U. Tezel, J. Pierson, S. Pavlostathis, "Effect of Polyelectrolytes and Quaternary Ammonium Compounds on the Anaerobic Biological Treatment of Poultry Processing Wastewater," Water Research, Vol. 41, No. 6, 2007, pp. 1334-1342. doi:10.1016/j.watres.2006.12.005

[8] P. Fernandez, A. Alder, J. Marc and W. Giger, "Deter- 
mination of the Quaternary Ammonium Surfactant Ditallowdimethylammonium in Digested Sludges and Marine Sediments by Supercritical Fluid Extraction and Liquid Chromatography with Postcolumn Ion-Pair Formation," Analytical Chemistry, Vol. 68, No. 5, 1996, pp. 921-929. doi:10.1021/ac9505482

[9] F. Merino, S. Rubio and D. Perez-Bendito, "Mixed Aggregate-Based Acid-Induced Cloud-Point Extraction and Ion-Trap Liquid Chromatography-Mass Spectrometry for the Determination of Cationic Surfactants in Sewage Sludge," Journal of Chromatography A, Vol. 998, No. $1-2,2003$, pp. 143-154. doi:10.1016/S0021-9673(03)00565-X

[10] H. Sutterlin, R. Alexy, A. Coker and K. Kummerer, "Mixtures of Quaternary Ammonium Compounds and Anionic Organic Compounds in the Aquatic Environment: Elimination and Biodegradability in the Closed Bottle Test Monitored by LC-MS/MS," Chemosphere, Vol. 72, No. 3, 2008, pp. 479-484.

doi:10.1016/j.chemosphere.2008.03.008

[11] S. Mishra and D. Panda, "Studies on the Adsorption of Brij-35 and CTAB at the Coal-Water Interface," Journal of colloid and interface science, Vol. 283, No. 2, 2005, pp. 294-299. doi:10.1016/j.jcis.2004.09.017

[12] M. Ghiaci, R. Kia and R. Kalbasi, "Investigation of Thermodynamic Parameters of Cetyl Pyridinium Bromide Sorption onto ZSM-5 and Natural Clinoptilolite," The Journal of Chemical Thermodynamics, Vol. 36, No. 2, 2004, pp. 95-100. doi:10.1016/i.jct.2003.09.002

[13] C. Basar, A. Karagunduz, A. Cakici and B. Keskinler, "Removal of Surfactants by Powdered Activated Carbon and Microfiltration," Water Research, Vol. 38, No. 8, 2004, pp. 2117-2124. doi:10.1016/j.watres.2004.02.001

[14] O. Duman and E. Ayranci, "Adsorptive Removal of Cationic Surfactants from Aqueous Solutions onto High-Area Activated Carbon Cloth Monitored by in Situ UV Spectroscopy," Journal of Hazardous Materials, Vol. 174 , No. 1-3, 2010, pp. 359-367. doi:10.1016/j.jhazmat.2009.09.058

[15] H. Tamai, M. Kunihiro and H. Yasuda, "Adsorption of Tetraalkylammonium Ions on Microporous and Mesoporous Activated Carbons Prepared from Vinylidene Chloride Copolymer," Journal of Colloid and Interface Science, Vol. 275, No. 1, 2004, pp. 44-47. .doi:10.1016/j.jcis.2003.12.039

[16] J. Laurent, M. Pierra, M. Casellas and C. Dagot, "Fate of Cadmium in Activated Sludge after Changing Its Physico-Chemical Properties by Thermal Treatment," Chemosphere, Vol. 77, No. 6, 2009, pp. 771-777. doi:10.1016/j.chemosphere.2009.08.024

[17] V. Ochoa-Herrera and R. Sierra-Alvarez, "Removal of Perfluorinated Surfactants by Sorption onto Granular Activated Carbon, Zeolite and Sludge," Chemosphere, Vol. 72 , No. 10,2008 , pp. $1588-1593$. doi:10.1016/j.chemosphere.2008.04.029

[18] A. Kipopoulou, A. Zouboulis, C. Samara and T. Kouimtzis, "The Fate of Lindane in the Conventional Activated Sludge Treatment Process," Chemosphere, Vol. 55, No. 1,
2004, pp. 81-91. doi:10.1016/j.chemosphere.2003.11.020

[19] M. Clara, S. Scharf, C. Scheffknecht and O. Gans, "Occurrence of Selected Surfactants in Untreated and Treated Sewage," Water Research, Vol. 41, No. 19, 2007, pp. 4339-4348. doi:10.1016/j.watres.2007.06.027

[20] M. Garcia, E. Campos, J. Sanchez-Leal and F. Comelles, "Sorption of Alkyl Benzyl Dimethyl Ammonium Compounds by Activated Sludge," Journal of Dispersion Science and Technology, Vol. 27, 2006, pp. 739-744. doi:10.1080/01932690600662554

[21] Z. Ismail, U. Tezel and S. Pavlostathis, "Sorption of Quaternary Ammonium Compounds to Municipal sludge," Water Research, Vol. 44, No. 7, 2010, pp. 2303-2313. doi:10.1016/j.watres.2009.12.029

[22] C. Zhang, U. Tezel, K. Li, D. Liu, R. Ren, J. Du and S. Pavlostathis, "Evaluation and Modeling of Benzalkonium Chloride Inhibition and Biodegradation in Activated Sludge," Water Research, Vol. 45, No. 3, 2011, pp. 1238-1246. doi:10.1016/j.watres.2010.09.037

[23] M. Idouhar and A. Tazerouti, "Spectrophotometric Determination of Cationic Surfactants Using Patent Blue V: Application to the Wastewater Industry in Algiers," Journal of Surfactants and Detergents, Vol. 11, No. 4, 2008, pp. 263-267. doi:10.1007/s11743-008-1079-1

[24] X. Wang, G. Yin, Q. Liu, et al., "The Monitoring Analysis Method of Water and Waste Water," $4^{\text {th }}$ Edition, China Environmental Protection Agency, China Environmental Science Press, 2002.

[25] M. Garcia, E. Campos, J. Sanchez-Leal and F. Comelles, "Structure-Activity Relationships for Sorption of Alkyl Trimethyl Ammonium Compounds on Activated Sludge," Tenside, Surfactants, Detergents, Vol. 41, No. 5, 2004, pp. 235-239.

[26] M. Chiou and H. Li, "Adsorption Behavior of Reactive Dye in Aqueous Solution on Chemical Cross-Linked Chitosan Beads," Chemosphere, Vol. 50, No. 8, 2003, pp. 1095-1105. doi:10.1016/S0045-6535(02)00636-7

[27] D. Ju, I. Byun, J. Park, C. Lee, G. Ahn and T. Park, "Biosorption of a Reactive Dye (Rhodamine-B) from an Aqueous Solution Using Dried Biomass of Activated Sludge," Bioresource Technology, Vol. 99, No. 17, 2008, pp. 7971-7975. doi:10.1016/j.biortech.2008.03.061

[28] S. Lagergren, "Zur Theorie der Sogenannten Adsorption gel Ster Stoffe, Kungliga Svenska Vetenskapsakademiens," Handlingar, Vol. 24, No. 4, 1898, pp. 1-39.

[29] Y. Ho and G. McKay, "The Kinetics of Sorption of Divalent Metal Ions onto Sphagnum Moss Peat," Water Research, Vol. 34, No. 3, 2000, pp. 735-742. doi:10.1016/S0043-1354(99)00232-8

[30] Y. Ho, G. McKay, D. Wase and C. Forster, "Study of the Sorption of Divalent Metal Ions on to Peat," Adsorption Science \& Technology, Vol. 18, No. 7, 2000, pp. 639-650. doi: $10.1260 / 0263617001493693$

[31] R. Juang, F. Wu and R. Tseng, "Mechanism of Adsorption of Dyes and Phenols from Water Using Activated Carbons Prepared from Plum Kernels," Journal of Colloid and Interface Science, Vol. 227, No. 2, 2000, pp. 
437-444. doi:10.1006/jcis.2000.6912

[32] Y. Shu, L. Li, Q. Zhang and H. Wu, "Equilibrium, Kinetics and Thermodynamic Studies for Sorption of Chlorobenzenes on CTMAB Modified Bentonite and Kaolinite," Journal of Hazardous Materials, Vol. 173, No. 1-3, 2010, pp. 47-53. doi:10.1016/j.jhazmat.2009.08.043

[33] G. Walker, L. Hansen, J. Hanna and S. Allen, "Kinetics of a Reactive Dye Adsorption onto Dolomitic Sorbents," Water Research, Vol. 37, No. 9, 2003, pp. 2081-2089. doi:10.1016/S0043-1354(02)00540-7

[34] N. Caner, I. Kiran, S. Ilhan and C. Iscen, "Isotherm and Kinetic Studies of Burazol Blue ED Dye Biosorption by Dried Anaerobic Sludge," Journal of Hazardous Materials, Vol. 165, No. 1-3, 2009, pp. 279-284. doi:10.1016/j.jhazmat.2008.09.108

[35] I. Mall, V. Srivastava, N. Agarwal and I. Mishra, "Adsorptive Removal of Malachite Green Dye from Aqueous Solution by Bagasse Fly Ash and Activated Carbon-Kinetic Study and Equilibrium Isotherm Analyses," Colloids and Surfaces A: Physicochemical and Engineering Aspects, Vol. 264, No. 1-3, 2005, pp. 17-28. doi:10.1016/j.colsurfa.2005.03.027

[36] I. Langmuir, "The Adsorption of Gases on Plane Surfaces of Glass, Mica and Platinum," Journal of the American Chemical Society, Vol. 40, No. 9, 1918, pp. 1361-1403. doi:10.1021/ja02242a004

[37] H. Freundlich, "Over the Adsorption in Solution," The Journal of Chemical Physics, Vol. 57, 1906, pp. 385-470.

[38] U. Tezel, J. Pierson and S. Pavlostathis, "Fate and Effect of Quaternary Ammonium Compounds on a Mixed Methanogenic Culture," Water Research, Vol. 40, No. 19, 2006, pp. 3660-3668. doi:10.1016/j.watres.2006.06.019

[39] H. Park and C. Na, "Adsorption Characteristics of Anionic Nutrients onto the PP-g-AA-Am Non-Woven Fabric Prepared by Photoinduced Graft and Subsequent Chemical Modification," Journal of Hazardous Materials, Vol. 166, No. 2-3, 2009, pp. 1201-1209.

[40] H. Senturk, D. Ozdes, A. Gundogdu, C. Duran and M. Soylak, "Removal of Phenol from Aqueous Solutions by Adsorption onto Organomodified Tirebolu Bentonite: Equilibrium, Kinetic and Thermodynamic Study," Journal of Hazardous Materials, Vol. 172, No. 1, 2009, pp.
353-362. doi:10.1016/j.jhazmat.2009.07.019

[41] W. Cheng, S. Wang, L. Lu, W. Gong, X. Liu, B. Gao and H. Zhang, "Removal of Malachite Green (MG) from Aqueous Solutions by Native and Heat-Treated Anaerobic Granular Sludge," Biochemical Engineering Journal, Vol. 39, No. 3, 2008, pp. 538-546.

doi:10.1016/j.bej.2007.10.016

[42] W. Weber Jr and W. Huang, "A Distributed Reactivity Model for Sorption by Soils and Sediments. Intraparticle Heterogeneity and Phase-Distribution Relationships under Nonequilibrium Conditions," Environmental Science \& Technology, Vol. 30, No. 3, 1996, pp. 881-888.

[43] J. Yang, "Fate and Effect of Alkyl Benzyl Dimethyl Ammonium Chloride in Mixed Aerobic and Nitrifying Cultures," MS Thesis, Georgia Institute of Technology, Atlanta, GA, 2007.

[44] K. Xu, W. Harper Jr and D. Zhao, " $17 \alpha$-Ethinylestradiol Sorption to Activated Sludge Biomass: Thermodynamic Properties and Reaction Mechanisms," Water Research, Vol. 42, No. 12, 2008, pp. 3146-3152. doi:10.1016/j.watres.2008.03.005

[45] V. Garg, R. Gupta, A. Bala Yadav and R. Kumar, "Dye Removal From Aqueous Solution by Adsorption on Treated Sawdust," Bioresource Technology, Vol. 89, No. 2, 2003, pp. 121-124. doi:10.1016/S0960-8524(03)00058-0

[46] Y. Feng, Z. Zhang, P. Gao, H. Su, Y. Yu and N. Ren, "Adsorption Behavior of $\mathrm{EE}_{2}$ (17 $\alpha$-Ethinylestradiol) onto the Inactivated Sewage Sludge: Kinetics, Thermodynamics and Influence Factors," Journal of Hazardous Materials, Vol. 175, No. 1-3, 2009, pp. 970-976. doi:10.1016/j.jhazmat.2009.10.105

[47] S. Netpradit, P. Thiravetyan, S. Towprayoon, “Adsorption of Three Azo Reactive Dyes by Metal Hydroxide Sludge: Effect of Temperature, $\mathrm{pH}$, and Electrolytes," Journal of Colloid and Interface Science, Vol. 270, No. 2, 2004, pp. 255-261. doi:10.1016/j.jcis.2003.08.073

[48] M. Gorgenyi, J. Dewulf, H. Van Langenhove and K. Heberger, "Aqueous Salting-Out Effect of Inorganic Cations and Anions on Non-Electrolytes," Chemosphere, Vol. 65, No. 5, 2006, pp. 802-810. doi:10.1016/i.chemosphere.2006.03.029 